\title{
Al-Co-Sc-Ti (Aluminum-Cobalt-Scandium-Titanium)
}

\section{Raghavan}

The Al-rich region of this quaternary system was investigated by [2001Buk] at $600{ }^{\circ} \mathrm{C}$ and at a constant $\mathrm{Al}$ content of 86 at.\%. The four-phase equilibrium on this section is $(\mathrm{Al})+\mathrm{Co}_{2} \mathrm{Al}_{9}+\mathrm{ScAl}_{3}+\alpha \mathrm{TiAl}_{3}$, with no ternary or quaternary phases.

\section{Lower Order Systems}

At 86 at. $\% \mathrm{Al}$ and at $600{ }^{\circ} \mathrm{C}$, the $\mathrm{Al}-\mathrm{Co}, \mathrm{Al}-\mathrm{Sc}$, and $\mathrm{Al}-\mathrm{Ti}$ binary phase diagrams consist of $(\mathrm{Al})+\mathrm{Co}_{2} \mathrm{Al}_{9}$ (D8 $8_{d}$-type monoclinic), $(\mathrm{Al})+\mathrm{ScAl}_{3}\left(L 1_{2}, \mathrm{AuCu}_{3}\right.$-type cubic $)$, and $(\mathrm{Al})+\alpha \mathrm{TiAl}_{3}(t 132, \quad I 4 / \mathrm{mmm})$ respectively, with little solubility of the binary compounds in $(\mathrm{Al})$. The $\mathrm{Al}-\mathrm{Co}-\mathrm{Sc}$ system is reviewed in this issue. The Al-Co-Ti system was reviewed by [2005Rag]. No phase diagram information appears to be available for the Al-Sc-Ti system.

\section{Quaternary Phase Equilibria}

With starting metals of $99.999 \% \mathrm{Al}, 99.9 \% \mathrm{Co}, 99.9 \%$ Sc, and $99.9 \%$ Ti, [2001Buk] melted 16 alloys in an electric arc furnace under $\mathrm{Ar}$ atm. The alloys contained a constant 86 at. $\% \mathrm{Al}$, with $\mathrm{Co}, \mathrm{Sc}$ and $\mathrm{Ti}$ each varying from 0 to 14 at.\%. The alloys were annealed at $600{ }^{\circ} \mathrm{C}$ for 1 month and quenched in water. The phase equilibria were studied with optical microscopy, x-ray powder diffraction, and hardness measurements. The isothermal section at $600{ }^{\circ} \mathrm{C}$ and at 86 at.\% $\mathrm{Al}$ constructed by [2001Buk] is shown in Fig. 1. The section is characterized by the four-phase

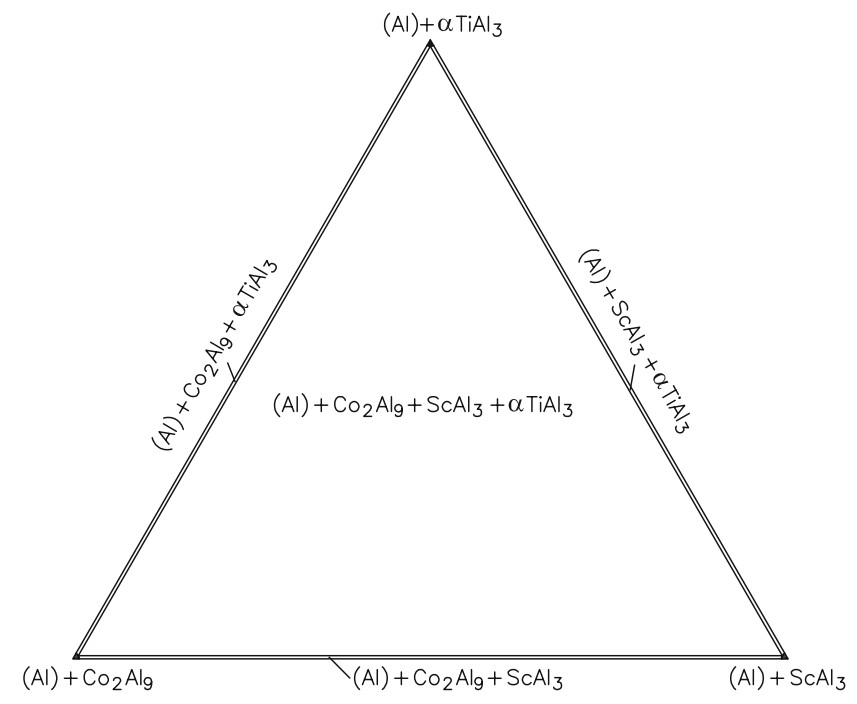

Fig. 1 Al-Co-Sc-Ti isothermal section at $600{ }^{\circ} \mathrm{C}$ and at 86 at.\% Al [2001Buk]

equilibrium of $(\mathrm{Al})+\mathrm{Co}_{2} \mathrm{Al}_{9}+\mathrm{ScAl}_{3}+\alpha \mathrm{TiAl}_{3}$. No ternary or quaternary phases were found.

\section{References}

2001Buk: N.G. Bukhanko, E.F. Kazakova, and E.M. Sokolovskaya, An Isothermal Section of the Quaternary System Al-Co-Sc-Ti, Vestn. Mosk. Univ., Ser. 2, Khimiya, 2001, 42(6), p 398-402, in Russian

2005Rag: V. Raghavan, Al-Co-Ti (Aluminum-Cobalt-Titanium), J. Phase Equilb. Diffus., 2005, 26(2), p 175-177 